\title{
RESEARCH NOTE \\ Alternative plants hosts of legume aphids and predators in the province of León, Spain
}

\author{
Isabel Bertolaccini ${ }^{1}$, Etelvina Núñez-Pérez ${ }^{2}$, and Emilio Jorge Tizado ${ }^{3}$ \\ 'Zoología Agrícola, Facultad de Ciencias Agrarias, Universidad Nacional del Litoral. R. P. Kreder, 2805, \\ 3080- Esperanza, Santa Fe, Argentina. \\ ${ }^{2}$ Departamento de Biología Animal, Zoología, Universidad de León, Campus de Ponferrada, E-24400 \\ Ponferrada, León, España. \\ ${ }^{3}$ Departamento de Biología Animal, Zoología, Universidad de León, Campus de Ponferrada, E-24400 \\ Ponferrada, León, España.
}

\begin{abstract}
I. Bertolaccini, E. Núñez-Pérez, and E. J. Tizado. 2011. Alternative plants hosts of legume aphids and predators, in the province of León (Spain). Cien. Inv. Agr. 38(2): 233-242. The study was done during the spring, summer and fall of 1998 and 1999. Samples were taken at random from legume crops and spontaneous plants adjacent to them in the province of León (Spain). Observations were made on the following crops: Medicago sativa, Phaseolus vulgaris, Pisum sativum, Cicer arietinum, Trifolium repens, Vicia fava, Trifolium pratense, Vicia ervilia, Lathyrus cicera, Lathyrus sativus, Trigonella foenum-graecum, Lupinus albus, Lupinus angustifolius and Lens esculenta. Twenty three families of spontaneous plants were observed. The aphid species and their population densities on the spontaneous plants and crop plants were recorded, as was the presence of members of the families Coccinellidae, Syrphidae and Chrysopidae. The plant families Brassicaceae, Asteraceae and Chenopodiaceae had the greatest numbers of these natural enemies of aphids the manipulation of spontaneous plants in agrosystems is a potential means of increasing populations of natural enemies of aphid pests in legume crops.
\end{abstract}

Key words: Biodiversity, Chrysopidae, Coccinellidae, Fabaceae, spontaneous plants, Syrphidae.

\section{Introduction}

As a whole, parasitoids and predators are the main natural enemies of aphids. The latter group includes representatives of the families Syrphidae, Coccinellidae and Chrysopidae.

The plant, pest, natural enemies (NEs) and environment must be considered for successful bio-

Received October 10, 2009. Accepted May 26, 2010.

Corresponding author: isabelb@fca.unl.edu.ar logical control $(\mathrm{BC})$ projects and integrated pest management (IPM) (Boiça et al., 2004). Plants have positive and negative as well as direct and indirect effects on herbivores and their NEs (Price et al., 1980; Robinson et al., 2008). The phytophagous community is influenced by plant richness and cover (Asteraki et al., 2004), which represent alternative food resources when pests are scarce and increase the impact of predators (Brewer and Elliott, 2004; Fitzgerald and Solomon, 2004).

The floristic composition and presence of flowering plants near or within productive systems 
promote increased numbers of Neuroptera (Ballal and Singh, 1999), Coccinellidae (Grez and Prado, 2000; Elliot et al., 2002; Banks and Yasenak, 2003) and Syrphidae (Frank, 1999; Sutherland et al., 2001). The flowers provide these insects with sources of nectar and pollen, which are essential for sexual maturation and egg production (Garcia, 1991; Hodek and Honek, 1996). Therefore, the predator species are available in the environment in case of pest presence in crops, allowing a reduced use of pesticides (Marshall and Moonen, 2002). The aim of this work was to determine which spontaneous plants in legume crops in the province of León are the best hosts of NEs of aphid pests, by serving as alternative prey or nectar and pollen suppliers for adults.

\section{Materials and methods}

In the Castilla and León Community (Spain), meat and milk production represents $36.56 \%$ of the total cattle production (Ciria, 2008). The province of León occupies $15.648 \mathrm{~km}^{2}$, and its main crops are cereals, legumes, tubers for human consumption, industrial crops and forage crops. Grain legume production became gradually important in regard to surface and production (Ciria, 2008). Cattle are raised on 13,500 ha of natural and cultivated grasslands. Alfalfa occupies $50 \%$ of the total surface area, while approximately 2500 ha are planted with other legumes used for animal feed (Boletín de Información Agraria de Castilla and León, 2009). The climate is close to continental oceanic, characterized by cold winters and hot summers with short spring and fall periods.

During the spring, summer and fall of 1998 and 1999, legume crops in the province of León (Spain) were randomly sampled. Five sampling sites on a transect in each lot were selected. First, Syrphidae and Neuroptera adults were recorded and captured during a 10-min period, as they are more mobile. Then, adult Coccinellidae and, finally, immature predators (Syrphidae, Neuroptera and Coccinellidae) were recorded and captured. The observations on the spontaneous plants were made in the same sequence, in both the interior and the edge of the lot. The abundance of aphids was determined based on direct observations, considering the presence of adults and colony formation. Aphid abundance was scored on a scale from 0 to 5 , where $0=$ absence of aphids; $1=$ presence of 1 adult, without nymphs, $2=$ presence of 1 to 3 adults; $3=$ presence of 4 to 10 adults; $4=$ presence of 11 to 20 adults; and $5=$ presence of 21 or more adults. Colony formation occurred at level 2 and higher.

Aphids were collected, and some were kept in alcohol $70^{\circ}$ for identification. The remaining aphids were bred on the plant portion on which they had been found, to detect the presence of immature stages that might have been unnoticed in the field observations.

The immature predators stages were individually placed in breeding flasks and fed Acyrthosiphon pisum that had been bred in the laboratory on Phaseolus vulgaris until adults were obtained. Laboratory-bred and field-collected aphids were preserved in alcohol $70^{\circ}$ until they were identified using a 40x binocular magnifying glass. The following keys were used for identification: Iablokoff- Khnzorian (1982), Stubbs and Falk (1983), Cardoso and Gomes Alves (1986), Majerus and Kearns (1989) and Rotheray (1989).

The aphids collected in field and preserved in alcohol $70^{\circ}$ were prepared according to the technique of Nieto Nafría and Mier Durante (1998). The keys by Lambers and Van den Bosch (1964), Nieto Nafría and Mier Durante (1984), Nieto Nafría et al. (1984), Remaudière and Seco Fernández (1990) and Heie (1992; 1995) were used as identification support.

We made a list of the aphids and the NEs of the families Coccinellidae, Syrphidae and Chrysopidae, per legume crop and per spontaneous plant species.

The taxonomic determination, as well as the scientific names, and authorship of the spontaneous plants were made according to the Missouri Botanical Garden and their website, Trópicos. org (2010). 


\section{Results}

\section{Legume crops}

We made 309 observations, of which 78\% corresponded to Medicago sativa L., and the remainder corresponded to Phaseolus vulgaris $\mathrm{L}$. (9\%), Pisum sativum L. (3.3\%), Cicer arietinum $\mathrm{L}$ and Trifolium repens L. (3\%) and Vicia faba $\mathrm{L}$. and Trifolium pratense L. (2\%). Other, less frequently observed crops included Vicia ervilia L. Willd, Lathyrus cicera L., Lathyrus sativus L., Trigonella foenum-graecum L., Lupinus albus L., L. angustifolius L. and Lens esculenta L.

The aphids Acyrthosiphon pisum (Harris); Aphis fabae Scopoli; A. craccivora Koch, Therioaphis trifolii (Monell); and Megoura viciae Buckton were identified. The numbers recorded for each species were 95 for $A$. pisum, 73 for $T$. trifoli, 72 for $A$. craccivoraand 31 for $A$. fabae. The greatest number of aphid observations corresponded to level 1 on our abundance scale, especially in M. sativa (159 observations).

Of the 180 Syrphidae observations, 165 were made in alfalfa (Table 1), and 27 species belonging to 11 genera were identified, including Dasysyrphus albostriatus (Fallén), D. hilaris (Zetterstedt), D. pinastri (De Geer) (=D. lunulatus (Meigen)), Episyrphus balteatus (De Geer), Melanostoma sp., M. dubium (Zettersted), M. mellinum (L.), M. scalare (F.), Metasyrphus latifasciatus (Marcquat), M. luniger (Meigen), M. nielseni Dùsek \& Láska, Paragus albifrons (Fallén), P. haemorrhous Meigen, P. tibialis (Fallén), P. quadrifasciatus Meigen, Platycheirus fulvi- ventris (Macquart), $P$. perpallidus Verrall, $P$. scutatus (Meigen), Scaeva albomaculata (Macquart), Sphaerophoria sp.., S. rueppellii (Wiedemann), S. scripta (L.); S. taeniata (Meigen), Syritta pipiens (L.), Syrphus ribesii (L.), S. vitripennis Meigen and Xanthandrus comtus (Harris).

The most frequent species in alfalfa were $S$. scripta, $S$. rueppellii, E. balteatus, $S$. ribessi and P. haemorrhous (54, 45, 14, 9 and 6 observations, respectively). The most abundant species in $V$. faba, V. sativa and P. vulgaris were $S$. scripta and S. rueppellii, which were found at level 3 of aphid abundance, while E. balteatus and S. rueppellii were found at each level. Melanostoma mellinum, $S$. rueppellii, $M$. luniger, $P$. albifrons, $P$. quadrifasciatus, $S$. albomaculata, S. pipiens, $S$. ribesii, S. scripta and $S$. taeniata were observed less frequently in T. repens, $P$. vulgaris and $M$. sativa and in the absence of Aphididae.

The Chrysopidae species identified were Chrysopa ciliata Wesmael and Chrysoperla carnea (Stephens), which were most often observed in the alfalfa crop, generally in the absence of aphids. We made 397 observations of Coccinellidae, identifying the species Adalia decempunctata (L.), Coccidula rufa Herbst, Coccinella quinquepunctata L., C. septempunctata L., Coccinula quatuordecimpustulata (L.), Exochomus nigromaculatus (Goeze), Hippodamia variegata (Goeze), Hyperaspis illecebrosa Mulsant, H. reppensis Herbst, Propylaea quatuordecimpunctata (L.), Psyllobora vigintiduopunctata (L.), Scymnus apetzi Mulsant, Scymnus interruptus (Goeze), S. rufipes (F.), Scymnus sp., Subcoccinella vigintiquatuorpunctata (L.) and Tytthaspis sedecimpunctata (L.).

Table 1. Aphididae numbers by abundance rates, and total Coccinellidae, Syrphidae and Chrysopidae, in all developmental stages, in legume crops.

\begin{tabular}{|c|c|c|c|c|c|c|c|c|}
\hline \multirow[b]{2}{*}{ Crop } & \multicolumn{5}{|c|}{$\begin{array}{l}\text { Aphididae (observation numbers according to } \\
\text { abundance index) }\end{array}$} & \multirow{2}{*}{$\begin{array}{c}\text { Total } \\
\text { Coccinellidae }\end{array}$} & \multirow[b]{2}{*}{ Total Syrphidae } & \multirow{2}{*}{$\begin{array}{c}\text { Total } \\
\text { Chrysopidae }\end{array}$} \\
\hline & 1 & 2 & 3 & 4 & 5 & & & \\
\hline M. sativa & 159 & 39 & 31 & 9 & 4 & 167 & 165 & 65 \\
\hline P. vulgaris & 21 & 3 & 2 & 1 & 0 & 20 & 9 & 16 \\
\hline Other crops & 33 & 3 & 3 & 1 & 0 & 210 & 6 & 15 \\
\hline Total & 213 & 45 & 36 & 11 & 4 & 397 & 180 & 96 \\
\hline
\end{tabular}


The greatest number of observations were made in alfalfa crops, and the largest species diversity was also found in this species (Table 1) (15), possibly due to the constant presence of aphids.

\section{Spontaneous plants}

Were recorded 23 families of spontaneous plants of the following species:

Amaranthaceae: Amaranthus retroflexus (L.). Apiaceae (= Umbelliferae): Anthriscus caucalis Bieb, Caucalis platycarpos L., Daucus carota L., Eryngium campestre L., Foeniculum vulgare Miller, Tordylium maximum L.

Asteraceae (= Compositae): Achillea millefolium L., Anacyclus clavatus Pers., Andryala integrifolia L., Anthemis arvensis L., Arctium minus Bernh, Carduus tenuiflorus Curtis, Carlina corymbosa L., Centaurea calcitrapa L., Chondrilla juncea L., Cirsium sp. Millar, Circium arvense (L.) Scop., C. odontolepis Boiss. ex DC., C. vulgare (Savi) Ten., Conyza canadensis (L.) Cronq, Crepis capillaris (L.) Wallr., C. vesicaria L., Galinsoga parviflora Cav., Helianthus annuus L., Hypochoeris radicata L., Lactuca virosa L., Mantisalca salmantica (L.) Briq. \& Cavillier, Onopordum acanthium L., Picris echioides L., Scolymus hispanicus L., Senecio jacobaea L., Sonchus asper (L.) Hill, S. oleraceus L., Sonchus sp. L. and Taraxacum officinale F. H. Wigg.

Boraginaceae: Echium italicum L., Echium vulgare $\mathrm{L}$.

Brassicaceae (= Cruciferae): Brassica sp. L., Brassica nigra (L.) Koch, Capsella bursa-pastoris: (L.). Medicus, Hirschfeldia incana (L.) Lagr.-Fossat, Raphanus raphanistrum L. and Sisymbrium austriacum (Cav.) Rouy \& Fouc.

Caryophylaceae: Petrorhagia prolifera (L.) P.W. Ball \& Heyw., Saponaria officinalis L. and Stellaria media (L.) Will.

Chenopodiaceae: Chenopodium album L.

Clusiaceae (Guttiferaceae)= Hypericaceae: $\mathrm{Hy}$ pericum perforatum (L.) Hudson.

Convolvulaceae: Convolvulus arvensis $\mathrm{L}$.

Dipsacaceae: Dipsacus fullonum L., Scabiosa atropurpurea $\mathrm{L}$. and $S$. columbaria $\mathrm{L}$.

Fabaceae (= Leguminoseae): Adenocarpus complicatus (L.) Gay in Durien, Trifolium resupinatum L., T. pratense $\mathrm{L}$. and $T$. repens $\mathrm{L}$. Lamiacae: Mentha x rotundifolia (L.) Hudson.
Malvaceae: Malva sylvestris L.

Papaveraceae: Papaver rhoeas L.

Plantaginaceae: Plantago lanceolata $\mathrm{L}$.

Poaceae (= Gramineae): Lolium perenne L.

Polygonaceae: Polygonum aviculare L., Rumex sp. L., Rumex conglomeratus Murray and $R u$ mex crispus $\mathrm{L}$.

Resedaceae: Reseda luteola L.

Rosaceae: Fillipendula ulmaria (L.) Maxim. and Rubus ulmifolius Schott.

Rubiaceae: Galium sp. L., Galium mollugo L. and G. verum $\mathrm{L}$.

Salicaceae: Salix neotricha Görz and S. triandra L.

Scrophulariaceae: Verbascum pulverulentum Vill. Verbenaceae: Verbena officinalis L.

The number of records for each spontaneous species was variable and depended on the frequency with which they were found in the crops, as follows:

Between 1 and 5 observations: A. arvensis, $A$. minus, A. caucalis, A. clavatus, A. complicatus, A. integrifolia, B. nigra, Brassica sp., C. bursa-pastoris, C. arvensis, C. calcitrapa, C. canadensis, C. corymbosa, $C$. odontolepis, C. platycarpos, C. tenuiflorus, C. vesicaria, C. vulgare, E. italicum, E. vulgare, E. campestre, F. ulmaria, G. mollugo, G. parviflora, G. verum, Galium sp., $H$. annuus, $H$. perforatum, $H$. incana, $H$. radicata, L. perenne, M. salmantica, Mentha $x$ rotundifolia, $O$. acanthium, $P$. aviculare, $P$. lanceolata, $P$. persicaria, $P$. rhoeas, $R$. crispus, $R$. luteola, $R$. raphanistrum, R. ulmifolius, Rumex sp., S. atropurpurea, $S$. austriacum, $S$. columbaria, $S$. hispanicus, S. media, S. neotrica, S. triandra, Sonchus sp., T. maximum, T. officinalis, T. pratense, T. repens, T. resupinatum, $V$. officinalis, $V$. pulverulentum.

Between 6 and 10 observations: A. retroflexus, C. arvense, C. capillaris, C. juncea, D. follonum, M. sylvestris, S. jacobaea, T. officinale.

More than 10 observations: A. millefolium, $C$. album, D. carota, F. vulgare, $L$. virosa, $P$. echioides, S. asper.

Forty-nine aphid species were identified, including wandering species. With regard to pests 
of legume species, A. pisum and T. trifolii were not found because of their monoic holocyclic nature, while $A$. fabae and $A$. craccivora, dioic holocyclic species that are polyphagous in the secondary host (Nieto Nafría et al., 1984), were common. The genus Aphis was recorded in Asteraceae, although it was only abundant in $C$. arvense. Aphis fabae was common in adventitious plants, unlike in the crops, where variable abundance indexes were present.

For the Syrphidae, we obtained 285 records for each developmental stage, and 41 species were identified, including D. albostriatus (Fallén), D. hilaris (Zetterstedt), D. pinastri (Meigen), D. tricinctus (Fallén), Episyrphus balteatus (De Geer), Eristalis arbostorum (L.), E. nemorum (L.), E. tenax (L.), Leucozona glaucia (L.), M. dubium (Zetterstedt), M. mellinum (L.), M. scalare (Fabricius), Melanostoma sp., Metasyrphus nitens (Zetterstedt), M. lapponicus (Zetterstedt), Meta- syrphus sp., M. corollae (Fabricius), M. latilunulatus (Collin), M. latifasciatus (Marcquat), M. luniger (Meiger), M. nielseni Dùsek \& Láska, Paragus albifrons (Fallén), P. haemorrhous Meigen, $P$. quadrifasciatus Meigen, P. tibialis (Fallén), Parasyrphus nigritarsis (Zetterstedt), Platycheirus fulviventris (Macquart), P. perpallidus Verrall, P. scutatus (Meigen), Scaeva albomaculata (Macquart), S. pyrastri (Linnaeus), Sphaerophoria rueppellii (Wiedemann), S. scripta (Linnaeus), Sphaerophoria sp., S. taeniata (Meigen), Syritta pipiens (Linnaeus), Syrphus ribesii (Wiedemann), S. torvus Osten-Sacken, S. vitripennis Meigen and Xanthandrus comtus (Harris).

Umbelliferae was the family most frequently observed (144 observations) (Table 2), mostly in D. carota and for the genus Sphaerophoria, followed by Compositae (78) and Chenopodiaceae (18). Syrphidae were found in 12 families in the absence of aphids.

Table 2. Observations of Syrphidae species, by spontaneous plant family.

\begin{tabular}{|c|c|c|}
\hline \multirow{2}{*}{ Spontaneous plant family } & \multicolumn{2}{|l|}{ Syrphidae } \\
\hline & Species & Number \\
\hline Amaranthaceae & $\mathrm{Pa}, \mathrm{Sr}, \mathrm{Ss}$ & 4 \\
\hline Asteraceae & $\begin{array}{l}\text { Dl, Dt, Ea, Eb, En, Et, Lg, Mc, Md, Metasyrphus sp. A., Mla, Mn, Pa, Paragus sp., } \\
P h, P q u, P s, P t, S a, S p, S r, S r i, S s, S t, S t o, X c\end{array}$ & 78 \\
\hline Borraginaceae & Ss & 2 \\
\hline Caryophylaceae & $E b, M l$ & 5 \\
\hline Chenopodiaceae & $E b, E t, M l, M l u, M s, P h, S p$, Sphaerophoria sp., Sr, Ss, Sv, Xc & 18 \\
\hline Convolvulaceae & Ss, Sphaerophoria sp. & 2 \\
\hline Leguminoseae & $E b, S r$ & 2 \\
\hline Brassiceae & Paragus sp., Ph, Pt, Sp, Sr, Sri, Ss, St & 9 \\
\hline Dipsacaceae & $S p, S s$ & 2 \\
\hline Lamiaceae & $S r$ & 1 \\
\hline Malvaceae & Paragus sp., $S r$ & 2 \\
\hline Plantaginaceae & $M s, S s, X c$ & 3 \\
\hline Poaceae & Ss & 1 \\
\hline Polygonaceae & Mn, Paragus sp., $\mathrm{Pa}, \mathrm{Ss}, \mathrm{Sr}$ & 5 \\
\hline Rosaceae & $S r, S s$ & 3 \\
\hline Rubiaceae & Ss, Xc, Paragus sp. & 3 \\
\hline Umbelliferae & $\begin{array}{l}\text { Dl, Eb, En, Metasyrphus sp., Ml, Mn, Mni, Pa, Pn, Pqu, Ps, Pt, Sp, Spy, Sr, Ss, St, } \\
S v, X c\end{array}$ & 144 \\
\hline Verbenaceae & $S r$ & 1 \\
\hline
\end{tabular}

Syrphidae species references: $D l=D$. lunulatus; $D t=D$. tricinctus; Ea $=$ E. arbostorum; Eb=E. balteatus; En=E. nemorum; $E t=E$. tenax; $M c=M$. corollae; $M d=M$. dubium; $M l=M$ latifasciatus; $M l=M$. lunulatus; Mla $M$. lapponicus; $M l u=M$. luniger; $M m=M$. mellinum; $M n=M$. nitiens; $M n i=M$. nielseni; $M s=M$ scalare; $P a=P$. albifrons $; P h=P$. haemorrhous; $P n=P$. nigritarsis; Pqu $=$ P. quadrifasciatus; $P s=P$. scutatus; $P t=P$. tibialis; $S p=S$. pipiens; Spy= $S$. pyrastri; $S r=S$. rueppellii; $S r i=S$. ribesii; $S r u=S$. rufipes; $S s=S$. scripta; $S t=S$. taeniata; $S t o=S$. torvus; $S v=S$. vitripennis; $X_{c}=X$. comtus; 
Chrysopidae was the less frequent predator family. Three species were identified: $C$. carnea, $C$. ciliata and Chrysopa perla. Umbelliferae, with D. carota as the most important species, was the spontaneous plant family with the most observations (77), followed by Chenopodiaceae (11). There were records in the absence of aphids for $A$. retroflexus, E. italicum, E. vulgare, $C$. album, A. millefolium, A. minus, C. capillaris, M. salmantica, O. acanthium, S. jacobaea, $C$. arvensis, $R$. raphanistrum, D. follonum, T. resupinatum, D. carota and T. maximum. D. carota was the host plant for 36 of 78 egg observations and 14 of 20 adults.

The family Coccinellidae was observed 199 times in different developmental stages, in 17 spontaneous plant families (Table 3). The species diversity was lower than in the crops, consisting of Coccinella septempunctata (Linnaeus), Coccinula quatuordecimpustulata (Linnaeus), Exochomus nigromaculatus (Goeze), Hippodamia variegata (Goeze), Hypperaspis illecebrosa Muls, H. reppensis Herbst, Propylaea quatuordecimpunctata (Linnaeus), Psyllobora vigintiduopunctata (Linnaeus), Scymnus apetzi Mulsant, S. rufipes (Fabricius), Subcocci- nella vigintiquatuorpunctata $\mathrm{L}$. and Tytthaspis sedecimpunctata (Linnaeus).

Records were not obtained for Hypericaceae, Lamiaceae, Papaveraceae, Plantaginaceae, Scrophulariaceae or Verbenaceae. Umbelliferae was the family with the greatest number of observations and the highest specific diversity (44.9\%). The most important species were D. carota $(33.7 \%)$ and $F$. vulgare. The family Compositae accounted for $22.4 \%$ of total observations, of which $C$. arvense, A. millefolium and A. minus presented 9, 5 and 4 records, respectively. Other families observed were Chenopodiaceae and Amaranthaceae, although these families were less common, with 17 and 8 counts, respectively (Table 3 ). The most frequent developmental stage was adult because increased mobility allows the colonization of new environments.

The most frequent species were Hippodamia variegata and C. septempunctata (40.1 and $26.0 \%$, respectively) with more distribution in the different hosts. Other less abundant species were $C$. quatuordecimpustulata, E. nigromaculatus, T. sedecimpunctata and $P$. vigintiduopunctata.

Table 3. Observations of Coccinellidae species, by spontaneous plant family.

\begin{tabular}{|c|c|c|}
\hline \multirow[b]{2}{*}{ Spontaneous plant family } & \multicolumn{2}{|l|}{ Coccinellidae } \\
\hline & Species & Number \\
\hline Amaranthaceae & $C q, C s, E n, H v, T s$ & 8 \\
\hline Borraginaceae & $H v$ & 1 \\
\hline Caryophylaceae & $C q, H v, S v, T s$ & 1 \\
\hline Chenopodiaceae & $C s$ & 17 \\
\hline Compositae & $C q, C s, E n, E n, H i, H v, P q, P v, S r, T s$ & 44 \\
\hline Convolvulaceae & $H v$ & 1 \\
\hline Brassiceae & $C s, H v, P v$ & 13 \\
\hline Dipsacaceae & $C s, H v, P v$ & 7 \\
\hline Leguminoseae & Cs & 1 \\
\hline Malvaceae & $H v$ & 1 \\
\hline Poaceae & Cs & 1 \\
\hline Polygonaceae & $C s, H v, T s, P q$ & 8 \\
\hline Resedaceae & $H v$ & 1 \\
\hline Rosaceae & $C s$ & 1 \\
\hline Rubiaceae & $C s, H v$ & 2 \\
\hline Salicaceae & $C s$ & 3 \\
\hline Umbelliferae & $\mathrm{Cm}, \mathrm{Cq}, \mathrm{Cr}, \mathrm{Cs}, \mathrm{En}, \mathrm{Hr}, \mathrm{Hv}, \mathrm{Pq}, \mathrm{Sa}, \mathrm{Sr}, \mathrm{Sv}, \mathrm{Ts}$ & 88 \\
\hline
\end{tabular}




\section{Discussion}

The large number of observations of Syrphidae with low populations of Aphididae in legume crops may be due to the following: 1) adults feed on honeydew that they secrete (Shonouda et al., 1998); 2) they respond to flower density more than the natural habitat where they reside (Sutherland et al., 2001) or 3) they search for alternative food sources or places for ovipositional purposes (Shonouda et al., 1998).

Habitat heterogeneity, even on a small scale, increases NE attraction to flowers from spontaneous plants close to agricultural fields, which represent a resource for alternative foods (Sutherland et al., 2001). Compositae was the family with the most predator observations, presenting the largest diversity of genera and species, unlike the Umbelliferae observations.

Syrphidae visit a wide flower spectrum during their life cycles (Garcia, 1991; Salveter, 1998). Irvin and Wratten (1999) found pollen from 39 species in the digestive tract. In this study, they preferred Umbelliferae, Asteraceae and Chenopodiaceae because the flowers of these species are always open and their pollen and nectar are easily accessible (Tooker et al., 2006). The higher number of species in spontaneous plants than in crops shows that flower diversity contributes to an increase in other trophic levels. An unexpected result was obtained for Brassicaceae, unlike reports by Irvin and Wratten (1999) and Kennedy (2003).

Coccinelidae are strongly influenced by variation in the vegetal composition around crops. whose structure determines the local abundance of Coccinelidae (Elliott et al., 2002), with a lower species variation than in crops. The most abundant species were C. septempunctata and H. variegata. Umbelliferae and Compositae were the families with the most observations, due to the presence of prey and pollen for their development (Hodek and Honek, 1996). Records in Hypericaceae, Lamiaceae, Papaveraceae, Plantaginaceae, Scrophulariaceae and Verbenaceae were not obtained because these plants were possibly the least frequent species or because they were not preferred by these NEs. There were scarce records of Chrysopidae, but it was most often ob- served in the family Umbelliferae. Chyrysopidae are omnivorous, which is an advantage in annual agricultural systems, where prey availability fluctuates (Limburg and Rosenheim, 2001).

Weeds may be an option for reducing the number of crop Syrphidae (Irvin and Wratten, 1999) and insecticide application (Frank, 1999) because they increase the presence of generalist predators (Wilby and Thomas, 2002). The low records in Brassicaceae may be due to the presence of wax affecting the mobility and effectiveness of these predators (Eigenbrode et al., 1999).

Adequate habitat handling increases the NE effectiveness in the $\mathrm{BC}$ of crop pests, and vegetal diversity fosters their presence and permanence because it provides food (Lin et al., 2003; Thorbek and Bilde, 2004). Additionally, it improves growth conditions, reproduction and population shelter, but the effect on beneficial insect dynamics depends on the selection of the appropriate species for the adequate enemy (Fitzgerald and Solomon, 2004).

The population structure and diversity of NEs may be manipulated by an adequate variety of spontaneous plants (Tooker et al., 2006). The best families for preserving the predators studied are Umbelliferae, Compositae and Chenopodiaceae because these families might influence the migration and emigration taxes (Grez Prado, 2000), which diminish the number of aphids in legume crops. Their inclusion and conservation in agroecosystems must be included in IPM studies. Additionally, because Umbelliferae grow in crop borders, they do not compete with aphids for light, water or nutrients. The results of this study have implications for the $\mathrm{BC}$ of aphid pests, in terms of both adequate habitat handling (Irvin and Wratten, 1999) and providing information for the selection of adventitious plants for a variety of predator species from the families Coccinellidae, Syrphidae and Chrysopidae.

\section{Acknowledgements}

We thank FOMEC, Universidad Nacional del Litoral (Argentina) and Universidad de León (Spain). 


\title{
Resumen
}

\begin{abstract}
I. Bertolaccini, E. Núñez-Pérez y E. J. Tizado. 2011. Plantas hospedadoras alternativas de áfidos de leguminosas y sus predadores, en la provincia de León (España). Cien. Inv. Agr. 38(2): 233-242. Durante los meses de primavera, verano y otoño de 1998 y 1999 se observaron al azar cultivos de leguminosas, y las plantas espontáneas marginales e intercalares, en la provincia de León (España). Los cultivos muestreados fueron: Medicago sativa, Phaseolus vulgaris, Pisum sativum, Cicer arietinum, Trifolium repens, Vicia fava, Trifolium pratense, Vicia ervilia, Lathyrus cicera, Lathyrus sativus, Trigonella foenum-graecum, Lupinus albus, Lupinus angustifolio y Lens esculenta. Se observaron 23 familias de plantas espontáneas, en ellas y en los cultivos se identificaron los áfidos, su densidad poblacional y de los predadores de las familias Coccinellidae, Syrphidae Chrysopidae. Las familias con mayores registros de los enemigos naturales de los pulgones fueron: Apiaceae, Asteraceae y Chenopodiaceae para Syrphidae y Coccinellidae. Se concluye que el manejo de los agrosistemas, mediante la manipulación de las plantas espontáneas, constituiría un recurso a tener en cuenta para incrementar el potencial de los enemigos naturales de los áfidos plaga de los cultivos de leguminosas.
\end{abstract}

Palabras clave: Biodivesidad, Coccinellidae, Chrysopidae, Fabaceae, hospedadoras alternativas, Syrphidae.

\section{References}

Asteraki, E.J., B.J. Hart, T.C. Ings, and W.J. Manley. 2004. Factors influencing the plant and invertebrate diversity of arable field margins. Agriculture, Ecosystems and Environment 102:219-231.

Ballal, C.R., and S.P. Singh. 1999. Host plant-mediated orientational and ovipositional behavior of three species of chrysopids (Neuroptera: Chrysopidae). Biological Control 16:47-53.

Banks, J.E., and C.L. Yasenak. 2003. Effects of plot vegetation diversity and spatial scale on Coccinella septempunctata movement in the absence of prey. Entomologia Experimentalis et Applicata 108:197-204.

Boiça J., T. Monteiro dos Santos, and A.K. Kuranishi. 2004. Desenvolvimento larval e capacidade predatória de Cycloneda sanguinea (L.) e Hippodamia convergens Guérin-Men., alimentadas com Aphis gossypii Glover sobre cultivares de algodoeiro. Maringá 26:239-244.

Boletín de Información Agraria de Castilla y León. 2009. Boletín No 9. Junta de Castilla y León. Conserjería de Agricultura y Ganadería. 110 pp. Available online at: http://www.jcyl.es/ web/jcyl/AgriculturaGanaderia/es/Plantilla100/1251094574128 (Website accessed: May 18, 2010).
Brewer, M.J., and N.C. Elliott. 2004. Biological control of cereal aphids in North America and mediating effects of host plant and habitat manipulations. Annual Review of Entomology 49:219-42.

Cardoso R.A.A., and M.L. Gomes Alves. 1986. Revisao dos coccinelideos de Portugal. Universidade de Évora. 103 pp.

Ciria, J. 2008. El futuro de la ganadería en Castilla y León. 91-101. En: El futuro de la agricultura en Castilla y León. José A. Gómez-Limón (Coordinador). 246 pp. Available online at: http://www. itagra.com/proyecto.aspx?pid=48 (Website accessed: May 18, 2010).

Eigenbrode, S.D., N.N. Kabalo, and K.A. Stoner. 1999. Predation, behavior, and attachment by Chrysoperla plorabunda larvae on Brassica oleracea with different surface waxblooms. Entomologia Experimentalis et Applicata 90:225-235.

Elliott, N.C., R.W. Kieckhefer, and D.A. Beck. 2002. Effect of aphids and the surrounding landscape on the abundance of Coccinellidae in cornfields. Biological Control 24:214-220.

Fitzgerald J.D., and M.G. Solomon. 2004. Can flowering plants enhance numbers of beneficial arthropods in UK apple and pear orchards? Biocontrol Science and Technology 14:291-300.

Frank, T. 1999. Density of adult hoverflies (Dipt., Syrphidae) in sown weed strips and adjacent 
fields. Journal of Applied Entomology 12:240244.

Garcia, M. 1991. Ecologia nutricional de parasitoides e predadores terrestres. En: Panizzi A.R., and J.R. Parra. Introduçao à ecologia nutricional de insetos e suas implicaçoes no manejo de pragas. Edit. Manole. Sao Pablo, Brazil. p. 289-311.

Grez, A.A., and E. Prado. 2000. Effect of plant patch shape and surrounding vegetation on the dynamics of predatory coccinellids and their prey Brevicoryne brassicae (Hemiptera: Aphididae). Environmental Entomology 29:1244-1250.

Heie, O.E. 1992. Fauna entomológica Scandinávica. Vol. 25. The Aphidoidea (Hemiptera) of Fennoscandia and Denmark. IV. Family Aphididae: Part 1 of Tribe Macrosiphini of Subfamily Aphidinae. E. J. Brill/Scandinavian Science Press Ltd. 189 pp.

Heie, O.E. 1995. Fauna entomológica Scandinávica. Vol. 31. The Aphidoidea (Hemiptera) of Fennoscandia and Denmark. VI. Family Aphididae. Part 3 of tribe Macrosiphini of subfamily Aphidinae and family Lachnidae. E. J. Brill/Scandinavica Press. 222 pp.

Hodek, I., and A. Honek. 1996. Ecology of Coccinellidae. Kluwer Academic Publishers, Dordrecht, The Netherlands. 464 pp.

Iablokoff-Khnzorian, S.M. 1982. Les coccinelles. Coléoptères-Coccinellidae. Tribu Coccinellini des régions Paléarctique et Orientale. Societé Nouvelle des Ëditions Boubée. 586 pp.

Irvin N.A., and S.D. Wratten. 1999. The phenology and pollen feeding of three hover fly (Diptera: Syrphidae) species in Canterbury, New Zealand. New Zealand Journal of Zoology 26:105-115.

Kennedy, G.G. 2003. Tomato, pests, parasitoids and predators: Tritrophic interactions involving the Genus Lycopersicon. Annual Review of Entomology 48:51-72.

Lambers, D.H., and R. Van den Bosh. 1964. On the genus Therioaphis Walker 1870, with description of news species (Homoptera, Aphididae). Zoologishe Uerhandelingen 68:3-47.

Limburg D.D., and J.A. Rosenheim. 2001. Extrafloral nectar consumption and its influence on survival and development of an omnivorous predator, larval Chrysoperla plorabunda (Neuroptera: Chrysopidae). Environmental Entomology 30:595-604.

Lin, R., H. Liang, R. Zhang, C. Tian, and Y. Ma. 2003. Impact of alfalfa/cotton intercropping and management on some aphid predators in China. Journal of Applied Entomology 127:33-36.

Majerus, M., and P. Kearns. 1989. Ladybirds. Naturalists 'Handbooks 10. Richmond Publishing Co. Ltd. England. 103 pp.

Marshall E.J.P., and A.C. Moonen. 2002. Field margins in northern Europe: their functions and interactions with agriculture. Agriculture, Ecosystems and Environment 89:5-21.

Nieto Nafría, J.M., and M.P. Mier Durante. 1984. Claves para la identificación de la fauna española. 17. Los géneros de pulgones de España (Homoptera, Aphidoidea). Universidad de León. Secretariado de Publicaciones. León, España. 85 pp.

Nieto Nafría, J.M., and M.P. Mier Durante. 1998. Fauna Ibérica. Vol. 11. Hemiptera. Aphididae I. Museo Nacional de Ciencias Naturales y Consejo Superior de Investigaciones Agrícolas. 424 pp.

Nieto Nafría, J.M., T.E. Díaz González, and M.P. Mier Durante. 1984. Catálogo de los pulgones (Homoptera, Aphidoidea) de España y de sus plantas hospedadoras. Universidad de León. Servicio de Publicaciones. 174 pp.

Price, P.W., C.E. Boston, P. Gross, B.A. McPheron, J.N. Thompson, and A.E. Weis. 1980. Influence of plants on interactions between insects herbivores and natural enemies. Ann. Review Ecology and Systematic 11:41-65.

Remaudière, G., and V. Seco Fernández. 1990. Claves de pulgones alados de la región mediterránea. Vol. 1: Introducción y claves. Vol.2: Ilustraciones y lista alfabética de taxones. Edit. Universidad de León. León, España. 205 pp.

Robinson, K.A., M. Jonson, S.D. Wratten, M.R. Wade, and H.L. Buckley. 2008. Implications of floral resources for predation by an omnivorous lacewing. Basic and Applied Ecology 9:172-181.

Rotheray, G.E. 1989. Aphid predators. Naturalists Handbooks 11. The Richmond Publishing Co. Ltd. Slough. 77 pp.

Salveter, R. 1998. The influence of sown herb strip and spontaneous weeds on the larval stages of aphidophagous hoverflies (Diptera:Syrphidae). Journal of Applied Entomology 122:103-114.

Shonouda, M.L., S. Bombos, A.M. Shalaby, and S.I. Osman. 1998. Biological and chemical characterization of a kairomone excreted by the bean aphids, Aphis fabae Scop (Hom. Aphididae) and its affects on the predator Metasyrphus corollae Fabr. I Isolation, identifications and biossay of aphid-kairomone. Journal of Appied Entomology $122: 15-23$. 
Stubbs, A. and S. Falk. 1983. British hoverflies an illustrated identification guide. British Entomological and Natural History Society. 253 pp.

Sutherland, J.P., M.S. Sullivan, and G.M. Poppy. 2001. Distribution and abundance of aphidophagous hoverfies (Diptera: Syrphidae) in wildflower patches and field margin habitats. Agricultural and Forest Entomology 3:57-64.

Thorbek P., and T. Bilde. 2004. Reduced numbers of generalist arthropod predators after crop management. Journal of Applied Ecology 41:526-538.
Tooker, J.F., M. Hauser, and L.M. Hanks. 2006. Floral host plants of Syrphidae and Tachinidae (Diptera) of Central Illinois. Annals of the Entomological Society of America 99:97-112.

Tropicos.org. Missouri Botanical Garden. Available online at: http://www.tropicos.org (Website accessed: May 18, 2010).

Wilby, A., and M.B. Thomas. 2002. Are the ecological concepts of assembly and function of biodiversity useful frameworks for understanding natural pest control? Agricultural and Forest Entomology 4:237-243. 